\title{
PERBEDAAN KEMAMPUAN PEMECAHAN MASALAH MATEMATIS DAN KEMANDIRIAN BELAJAR SISWA MELALUI PENDEKATAN SCIENTIFIC DAN PENDEKATAN SCIENTIFIC BERBANTUAN SOFTWARE AUTOGRAPH
}

\author{
Rismalyah Manalu ${ }^{1}$, Elvis Napitupulu², Edi Syahputra ${ }^{2}$
}

\begin{abstract}
ABSTRAK
Tujuan dari penelitian ini adalah untuk : (1) Menguji dan menganalisis ada atau tidak perbedaan nyata mengenai efek dari pendekatan scientific berbantuan software Autograph dan pendekatan scientific terhadap kemampuan pemecahan masalah matematis siswa, 2) Menguji dan menganalisis ada atau tidak perbedaan nyata mengenai efek dari pendekatan scientific berbantuan software Autograph dan pendekatan scientific terhadap kemandirian belajar siswa, (3) Menguji dan menganalisis ada atau tidak efek interaksi antara pendekatan pembelajaran (scientific berbantuan software Autograph, scientific) dan kemampuan awal matematis (KAM) terhadap kemampuan pemecahan masalah matematis siswa, (4) Menguji dan menganalisis ada atau tidak efek interaksi antara pendekatan pembelajaran (scientific berbantuan software Autograph, scientific) dan kemampuan awal matematis (KAM) terhadap kemandirian belajar siswa. Adapun analisis data dilakukan dengan uji Analisis Varian Dua Jalur (ANAVA) dengan hasil penelitian yaitu: (1) Terdapat perbedaan nyata kemampuan pemecahan masalah matematis siswa yang diberi pendekatan scientific berbantuan software Autograph dan pendekatan scientific dengan efek pengaruhnya sebesar 0,4023. Adapun perolehan rata-rata kemampuan pemecahan masalah matematis yang diajarkan dengan pendekatan scientific berbantuan software Autograph adalah 79,78 sedangkan ratarata kelompok yang diajarkan dengan pendekatan scientific adalah sebesar 78,31 artinya kemampuan pemecahan masalah matematis siswa dengan pendekatan scientific berbantuan software Autograph lebih tinggi dari pendekatan scientific, (2) Terdapat perbedaan nyata antara kemandirian belajar siswa yang memperoleh pendekatan scientific berbantuan software Autograph dengan siswa yang memperoleh pendekatan scientific. Adapun besar efek pengaruh pendekatan pembelajaran $=0,0674$ berarti pendekatan pembelajaran dapat menjelaskan 6,74\% variansi skor kemandirian belajar siswa, (3) Tidak terdapat interaksi faktor pendekatan pembelajaran dan faktor KAM terhadap kemampuan pemecahan masalah matematis. Adapun besar pengaruh tidak terdapat interaksi antara pendekatan pembelajaran dan $\mathrm{KAM}=0,0587$, yang berarti tidak terdapat interaksi pendekatan pembelajaran dan KAM dapat menjelaskan 5,87\% variasi skor kemampuan pemecahan masalah matematis siswa, (4) Tidak terdapat interaksi faktor pendekatan pembelajaran dan faktor KAM terhadap kemandirian belajar siswa. Adapun besar pengaruh tidak terdapat interaksi antara pendekatan pembelajaran dan $\mathrm{KAM}=0,0457$ berarti tidak terdapat interaksi pendekatan pembelajaran dan KAM dapat menjelaskan $4,57 \%$ variasi skor kemandirian belajar siswa.
\end{abstract}

Kata Kunci: Pendekatan Scientific, Pendekatan Scientific Berbantuan Software Autograph, Pemecahan Masalah Matematis, Kemandirian Belajar Siswa

\section{PENDAHULUAN}

Pendidikan merupakan satu-satunya alat yang tepat untuk membangun sumber daya manusia

\footnotetext{
${ }^{1}$ Corresponding Author: Rismalyah Manalu

Program Magister Pendidikan Matematika, Universitas Negeri

Medan, Medan, 20221, Indonesia

E-mail: newrisma22@gmail.com

${ }^{2}$ Co-Author: E. Elvis Napitupulu \& Edi Syahputra

Program Studi Pendidikan Matematika, Universitas Negeri Medan, Medan, 20221, Indonesia
}

dengan kualitas yang tinggi, sehingga mampu bersaing dalam menghadapi tantangan globalisasi.

Peningkatan mutu pendidikan harus mengimplementasikan Standar Nasional Pendidikan dalam kurikulum sesuai tuntutan indikator pencapaian pembelajaran sesuai Undang-undang Nomor 20 Tahun 2003 (2003:2) tentang Sistem Pendidikan Nasional menyatakan bahwa: "Pendidikan Nasional berfungsi mengembangkan kemampuan dan membentuk

Perbedaan Kemampuan Pemecahan Masalah Matematis dan Kemandirian Belajar Siswa Melalui Pendekatan Scientific dan Pendekatan Scientific Berbantuan Software Autograph 


\section{PARADIKMA JURNAL PENDIDIKAN MATEMATIKA}

Vol. 13, No. 1, Juni 2020

watak serta peradaban bangsa yang bermartabat dalam rangka mencerdaskan kehidupan bangsa, bertujuan untuk mengembangkan potensi peserta didik agar menjadi manusia yang beriman dan bertaqwa kepada Tuhan Yang Maha Esa, berakhlak mulia, sehat, berilmu, cakap, kreatif, mandiri, dan menjadi warga negara yang demokratis serta bertanggung jawab. Adanya perwujudan pendidikan yang maju menjadikan dasar kemajuan suatu bangsa karena pendidikan bertujuan untuk mempersiapkan manusia Indonesia agar memiliki kemampuan hidup sebagai pribadi dan warga negara yang beriman, produktif, kreatif, inovatif, dan afektif serta mampu berkontribusi pada kehidupan bermasyarakat, berbangsa, bernegara, dan peradaban dunia".

Napitupulu (2008:24) mengungkapkan "sebagaimana bangsa-bangsa lain di muka bumi, Indonesia menumpuhkan harapan mencerdaskan dan memajukan kehidupan kebangsaan terutama melalui pendidikan formal dalam bentuk institusi sekolah. Semua bahan pembangun karakteristik dituangkan dalam sebuah dokumen yang disebut kurikulum". Daryanto (2014:1) menyatakan "kurikulum adalah suatu respon pendidikan terhadap kebutuhan masyarakat dan bangsa dalam membangun generasi muda bangsanya".

Kurniasih (2014:132) juga mengungkapkan "titik berat kurikulum 2013 bertujuan agar peserta didik memiliki kemampuan yang lebih baik dalam melakukan: observasi, bertanya (wawancara), bernalar, berkomunikasi (mempresentasekan) apa yang mereka peroleh atau mereka ketahui setelah menerima materi pembelajaran".

Sebagaimana dijelaskan BSNP (Badan Standar Nasional Pendidikan) yang termuat Permendiknas No.22 (2006:5) bahwa "matematika merupakan ilmu universal yang mendasari perkembangan teknologi modern yang mempunyai peran penting dalam berbagai disiplin dan memajukan kemampuan berpikir manusia". Baroody (Sofiyah, 2017:1-2) mengatakan "matematika memiliki peranan penting dalam pengembangan pikiran, memecahkan masalah dan tantangan yang ada dalam kemajuan ilmu pengetahuan dan teknologi serta menjadi alat dalam pemecahan masalah".

Pemecahan masalah merupakan suatu hal yang sangat esensial dalam pembelajaran matematika di sekolah, antara lain disebabkan: (1) siswa menjadi terampil menyeleksi informasi yang relevan, kemudian menganalisis dan meneliti hasilnya, (2) dapat menimbulkan kepuasan intelektual dari dalam diri siswa, (3) potensi intelektual siswa meningkat, (4) melatih siswa dalam menyelesaikan masalah. Napitupulu (2008) mengemukakan "pemecahan masalah tidak diragukan lagi merupakan jantungnya kegiatan bermatematika dan pembelajaran matematika". Adapun Charles, Lester, \& O'Daffer (Szetela dan Nicol, 1982) menyusun indikator dari setiap aspek atau tahap pemecahan masalah yaitu: "(1) Memahami Masalah (Understanding Problem), (2) Merencanakan Pemecahan Masalah (Solving the Problem), dan (3) Menyelesaikan Masalah (Answer the Problem)"

Namun, Hasratuddin

(2015:10) mengemukakan "dunia pendidikan Indonesia, saat ini sedang dihadapkan pada dua masalah besar yaitu mutu pendidikan yang masih rendah dan sistem pembelajaran di sekolah yang kurang memadai yang berdampak nyata dengan moralitas remaja yang rendah". Hasil diagnosis TIMSS 2015, Rahmawati (2016:3) mengungkapkan: "Secara umum, siswa Indonesia lemah di semua aspek konten maupun kognitif, baik untuk matematika maupun sains. Siswa Indonesia menguasai soal-soal yang bersifat rutin, komputasi sederhana, serta mengukur pengetahuan akan fakta yang berkonteks keseharian siswa. Indonesia perlu penguatan kemampuan mengintegrasikan informasi, menarik kesimpulan, serta menggeneralisir pengetahuan yang dimiliki ke hal-hal yang lain".

Berbagai artikel jurnal penelitian tentang analisis studi kemampuan pemecahan masalah antara lain: M. Sudirman, Fatimah, \& Jupri (2017) menganalisis: "kesalahan yang dilakukan oleh siswa SMA 14 Bandung kelas IX adalah tidak mengerti masalah yang diberikan sehingga siswa tidak dapat mengubah masalah menjadi model matematis, siswa tidak mengerti masalah yang diberikan sehingga strategi atau solusi siswa tidak tepat, strategi untuk mengubah masalah cerita masih lemah". Napitupulu, Suryadi dan Kusumah (2016) mengungkapkan: "Siswa tidak memiliki kemampuan untuk melihat hubungan antara faktafakta yang ada dan terkait dengan pengetahuan trigonometri yang relevan untuk menerjemahkan representasi masalah ke dalam representasi trigonometri dan kemudian ke persamaan matematika. Situasi ini menuntut siswa untuk menciptakan beberapa persamaan matematika dan sangat sulit untuk mereka penuhi”.

Hal ini juga secara spesifik berdasarkan hasil observasi guru di SMA Negeri 1 Medan masih menggunakan pola pembelajaran langsung pada peserta didik yang selama ini belum mampu mencapai indikator pembelajaran terkhusus dalam pemecahan masalah matematis, belum mampu 


\section{PARADIKMA JURNAL PENDIDIKAN MATEMATIKA}

Vol. 13, No. 1, Juni 2020

meningkatkan kemandirian belajar siswa dengan baik dan siswa belum mampu mencapai kriteria ketuntasan minimum (KKM) yang ditetapkan dalam sistem pendidikan dalam kurikulum 2013 terutama dalam pemecahan masalah matematis.

Berdasarkan hasil observasi tanggal 26 September 2017 di SMA Negeri 1 Medan bahwa siswa masih merasa kesulitan dalam memahami dan tidak mampu menyelesaikan soal pemecahan masalah matematis dengan kontekstual sederhana. Berikut ini soal pemecahan masalah matematis yang diberikan.

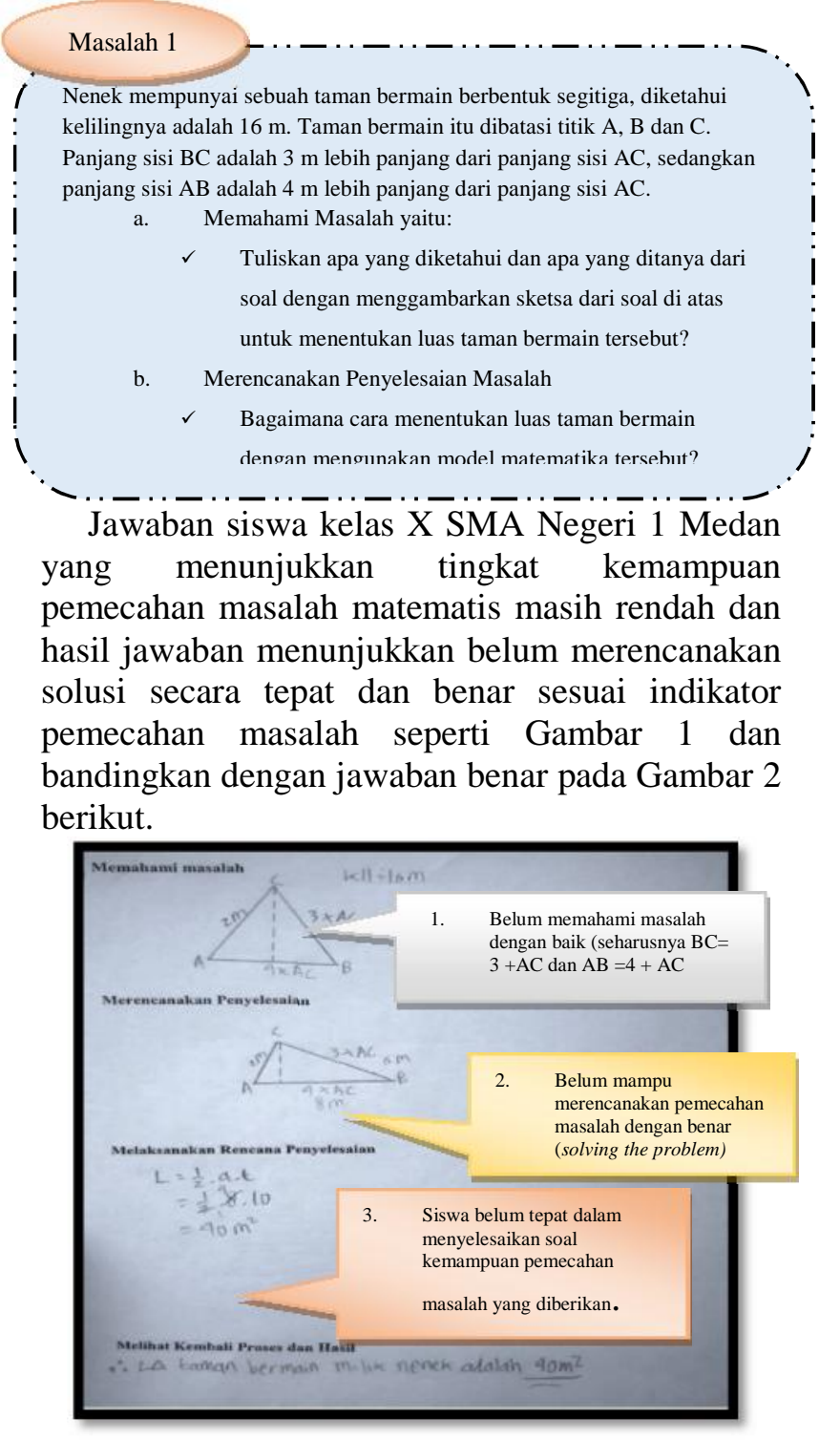

Gambar 1. Lembar Jawaban yang Benar

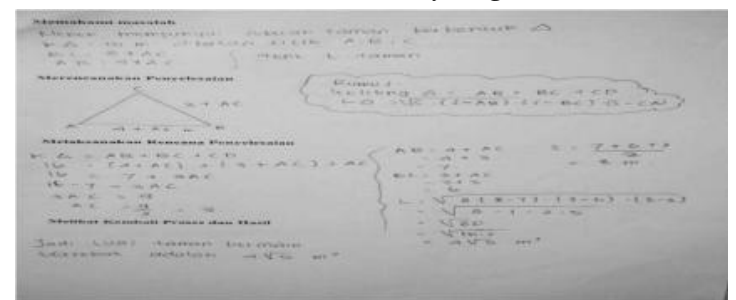

Dari analisis soal pendahuluan disimpulkan siswa masih lemah dalam memahami masalah, merencanakan strategi permasalahan, menyelesaikan masalah, tidak mampu menghubungkan konsep segitiga dan penalaran matematis siswa masih lemah. Kemampuan pemecahan masalah matematis siswa di SMA Negeri 1 Medan masih rendah dan jauh untuk dapat dikatakan tuntas. Dari hasil tes studi pendahuluan kemampuan pemecahan masalah matematis kepada 25 siswa, rata-rata skor yang diperoleh siswa adalah 40,63 maka kemampuan pemecahan masalah matematis siswa SMA Negeri 1 Medan masih kategori kurang, sesuai Peraturan Permendikbud No. 23 Tahun 2016 Bab VI Tentang Prosedur Penilaian Pasal 12 Ayat 2C.

Rendahnya kemampuan pemecahan masalah matematis disebabkan di sekolah ini pembelajaran masih berpusat pada guru (teacher oriented) menggunakan pelajaran langsung yang dianggap guru selama ini cukup efektif, dan guru masih terkendala dalam melaksanakan kurikulum 2013 yang menuntut guru harus kreatif dalam mengembangkan pola berpikir siswa dalam soal pemecahan masalah. Strategi pembelajaran langsung belum mampu membina dan mengembangkan kemampuan belajar siswa, siswa cenderung belajar pasif menimbulkan siswa kurang kritis dalam memahami soal pemecahan masalah. Juliana dan Surya (2017) mengemukakan: "proses belajar mengajar matematika akan bermakna jika bahan yang diberikan oleh guru kepada siswa dapat dipahami". Perlu proses yang benar dan cara yang benar sehingga pembelajaran yang diberikan dapat dipahami oleh siswa, salah satunya adalah menciptakan pembelajaran yang efektif. Menurut Yuniara dan Surya (2017) bahwa:" pemilihan strategi pembelajaran dan memilih model pembelajaran merupakan salah satu solusi untuk mencapai keberhasilan pembelajaran".

Selain pemecahan masalah, pemerintah menjelaskan pentingnya kemandirian belajar bagi peserta didik, ini tertuang dalam PP No.32 Tahun 2005 Bab IV Pasal 19 (2005:12) yakni: Tentang Standar Proses yakni proses pembelajaran pada satuan pendidikan diselenggarakan secara interaktif, inspiratif, menyenangkan, menantang, memotivasi peserta didik untuk berpartisipasi aktif, serta memberikan ruang yang cukup bagi prakarsa, kreativitas, dan kemandirian sesuai dengan bakat, minat, dan perkembangan fisik serta psikologis peserta didik. 
Adapun beberapa komponen yang digunakan untuk mengukur kemandirian belajar berdasarkan modifikasi Zimmerman (1988:287) yaitu: (1) Evaluasi terhadap kemajuan tugas (self evaluating), 2) Mengatur materi pelajaran (organizing and transforming), 3) Membuat rencana dan tujuan belajar (goal setting and planning), 4) Mencari informasi (seeking information), 5) Mengatur lingkungan belajar (enviromental structuring), 6) Mengulang dan mengingat (rehearsing and memorizing), 7) Meminta bantuan teman, guru, orang dewasa (seeking peer, teacher, adult assistence), dan 8) Mengulang tugas / tes sebelumnya (review test/work).

Berdasarkan pendapat di atas, menunjukkan bahwa kemandirian belajar matematika menjadi salah satu faktor penting yang menentukan keberhasilan belajar siswa khususnya yang terkait dengan kemampuan pemecahan masalah matematis siswa. Pape \& Smith (2002:56) menyatakan "clearly express how the processes of problem solving and self-regulation are closely linked to each other", artinya bagaimana proses penyelesaian masalah dan pengaturan diri terkait erat satu sama lain.

Selain itu, pengembangan kemandirian belajar sangat diperlukan oleh individu yang belajar matematika karena akan berdampak efektif dan efisien dalam mengatur proses belajarnya sehingga menjadi lebih baik lagi. Namun, kemandirian belajar siswa masih rendah sesuai dengan fakta yang terlihat di lapangan. Dari hasil angket yang diberikan peneliti kepada 25 siswa di kelas X SMA Negeri 1 Medan, diperoleh kesimpulan bahwa: (1) 65\% siswa belum mampu mengevaluasi terhadap kemajuan tugas (self evaluating), (2) $55 \%$ siswa belum mengatur materi pelajaran (organizing and transforming), (3) $65 \%$ siswa belum membuat rencana dan tujuan belajar (goal setting and planning), (4) 60\% siswa belum bisa memanfaatkan dan mencari sumber yang relevan, dan (5) 65\% siswa belum bisa memilih dan menerapkan strategi belajarnya.

Di samping kemampuan pemecahan masalah matematis dan kemandirian belajar (self-regulated learning), faktor lain yang dapat berkontribusi yaitu kemampuan awal matematis (KAM) yang merupakan gambaran kemampuan dasar yang perlu diperhatikan guru dalam belajar matematika. Menurut Uno (2011:159) mengungkapkan bahwa "kemampuan awal amat penting peranannya dalam meningkatkan kebermaknaan pembelajaran, yang selanjutnya membawa dalam memudahkan proses internal yang berlangsung dalam diri siswa ketika belajar". Dimana KAM memiliki hubungan positif terhadap hasil belajar siswa dan KAM juga dapat memprediksi keberhasilan belajar siswa pada masa selanjutnya, baik dalam materi itu sendiri maupun ilmu lain secara luas.

Senada dengan Andriani (2017:2) mengemukakan bahwa "KAM siswa yang dibedakan ke dalam kelompok tinggi, sedang dan rendah. KAM dan pendekatan pembelajaran diduga berinteraksi terhadap kemampuan pemecahan masalah matematis yang akhirnya dapat mempengaruhi hasil belajar matematika". Setiap siswa memiliki KAM yang berbeda dan kemampuan yang dimiliki yang dimiliki bukan semata-mata bawaan lahir (hereditas) tetapi juga dipengaruhi oleh lingkungan. Oleh karena itu, pemilihan lingkungan belajar khususnya pendekatan pembelajaran menjadi sangat penting untuk dipertimbangkan artinya dalam pemilihan pendekatan pembelajaran harus dapat meningkatkan kemampuan matematis siswa yang heterogen.

Dengan menggunakan software Autograph pada materi persamaan dan pertidaksaaan nilai mutlak linear satu variabel, siswa menggambarkan setiap grafik persamaan dan pertidaksaaan nilai mutlak linear satu variabel membutuhkan waktu yang lebih cepat dan efektif. Siswa hanya perlu menentukan konsep persamaan dan pertidaksamaan secara matematis dan mendapatkan gambar yang diinginkan dengan bantuan Autograph. Sehingga, kesempatan siswa untuk mengembangkan dan menjelajah lebih besar. Hal tersebut diharapkan dapat berpengaruh kepada penanaman konsep dasar yang nantinya akan meningkatkan kemampuan pemecahan masalah matematis dan kemandirian belajar siswa.

Dewan Riset Nasional (Karnasih, 2014:45) mengungkapkan "keberhasilan proses pemecahan masalah matematis tergantung pada reprensentasi pemecahan masalah dari masalah tersebut". Selain itu, Fyle \& Jhonson (2016:140) mengungkapkan: "Results suggest that minimal computer-generated feedback can be a powerful form of guidance during problem solving" artinya hasilnya menunjukkan bahwa umpan balik yang dihasilkan komputer menjadi bentuk bimbingan yang kuat selama penyelesaian masalah.

Pembelajaran matematika dalam Kurikulum 2013 diterapkan di Indonesia menekankan pada dimensi pedagogik modern dalam pembelajaran, yaitu menggunakan pendekatan ilmiah (scientific approach) meliputi mengamati, menanya, menalar, mencoba, membentuk jejaring untuk semua pelajaran sesuai 


\section{PARADIKMA JURNAL PENDIDIKAN MATEMATIKA}

Vol. 13, No. 1, Juni 2020

Permendikbud RI No. 65 Tahun 2013. Selain itu, dalam kurikulum 2013 siswa dimotivasi untuk mengecek informasi baru dengan yang ada dalam ingatan siswa (Permendikbud RI No. 81A Tahun 2013). Salah satu solusi untuk mencapai pembelajaran adalah dengan menggunakan pendekatan scientific. Menurut Daryanto (2014:51) bahwa "Pendekatan saintifik dimaksudkan untuk memberikan pemahaman kepada peserta didik dalam mengenal, memahami berbagai materi mengunakan pendekatan ilmiah. Informasi berasal dari mana saja, kapan saja, tidak tergantung pada informasi searah dari guru. Oleh karena itu, kondisi pembelajaran yang diharapkan untuk mendorong peserta didik dalam mencari tahu dari berbagai sumber melalui observasi dan bukan hanya diberi tahu oleh guru. Selain itu, hasil penelitian M. Sudirman, Fatimah \& Jupri. (2017:254) adalah: "Pembelajaran ilmiah (Scientific Learning) melalui strategi pembelajaran kuantum yang diterapkan pada pembelajaran matematika di kelas XI SMA 14 Bandung dapat mengoptimalkan kemampuan belajar siswa sehingga siswa mampu membentuk kemampuan pemecahan masalah mereka dan Self Regulated Learning agar memperoleh hasil belajar matematika yang optimal dan dapat mencapai tujuan pembelajaran sesuai keinginan".

Sebagaimana ditetapkan dalam prinsip pembelajaran matematika sekolah oleh NCTM (2000:11) yaitu "Technology is essential in teaching and learning mathematics; it influences the mathematics that is taught and enhances students' learning". Hal yang sama dijelaskan dalam Permendiknas No. 65 (2013:7) bahwa "pemanfaatan Teknologi Informasi dan Komunikasi (TIK) dapat meningkatkan efisiensi dan efektifitas pembelajaran". Pembelajaran matematika dengan menggunakan media berbasis teknologi komputer sangat baik apabila mendukungnya dengan software-software matematika yang sangat membantu siswa dalam mengerjakan atau menganalisa persoalan yang ada. Seorang guru dituntut mampu menyesuiakan software yang digunakan dengan materi yang akan di ajarakan. Salah satu software yang dapat digunakan dalam pembelajaran matematika adalah Autograph. Menurut Karnasih (2014:151) bahwa: "Autograph adalah software yang dinamis dan serbaguna untuk belajar dan mengajar matematika pada siswa tingkat menengah yang dikembangkan oleh Douglas Butler. Software ini didisain untuk membantu guru dan siswa memvisualisasikan matematika dengan menggunakan 3 mode yaitu: a)1 dimensi untuk peluang dan statistik, b) 2 dimensi untuk grafik, koordinat, transformasi, dan data bivariat, dan c) 3 dimensi untuk grafik, koordinat dan transformasi pada ruang tiga dimensi seperti Gambar 3 berikut.

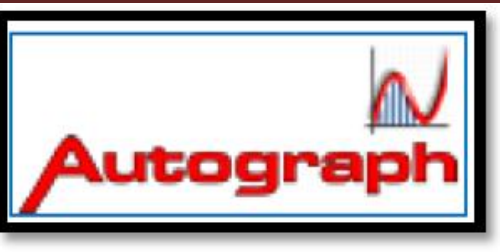

Gambar 3. Autograph Logo

Penelitian Karnasih \& Marianti (2014:51) menyimpulkan bahwa "Pembelajaran kooperatif dengan menggunakan Dynamic Software Autograph dalam mengajar Statistik di Kelas XI Medan meningkatkan kemampuan pemecahan masalah siswa. Hal ini dapat ditunjukkan dari hasil, bahwa ada peningkatan yang signifikan dalam kemampuan pemecahan masalah; $91,2 \%$ menyukai menggunakan Software dinamis dan diharapkan guru matematika harus mempertimbangkan penggunaan Dynamic Software Autograph dalam pengajaran dan pembelajaran matematika sekunder, terutama dalam pengajaran statistik dan pengajaran unit matematika lainnya seperti Aljabar, Geometri, Trigonometri dan Kalkulus".

Autograph sangat potensial untuk membantu siswa dalam soal pemecahan masalah 1 seperti masalah 1 pada materi menemukan konsep nilai mutlak. dan mampu meningkatkan kemandirian belajar siswa.

Penggunaan software Autograph dapat membantu pemahaman siswa dan juga menambah wawasan siswa dalam menyelesaikan soal Masalah 1 diatas seperti Gambar 4 berikut.
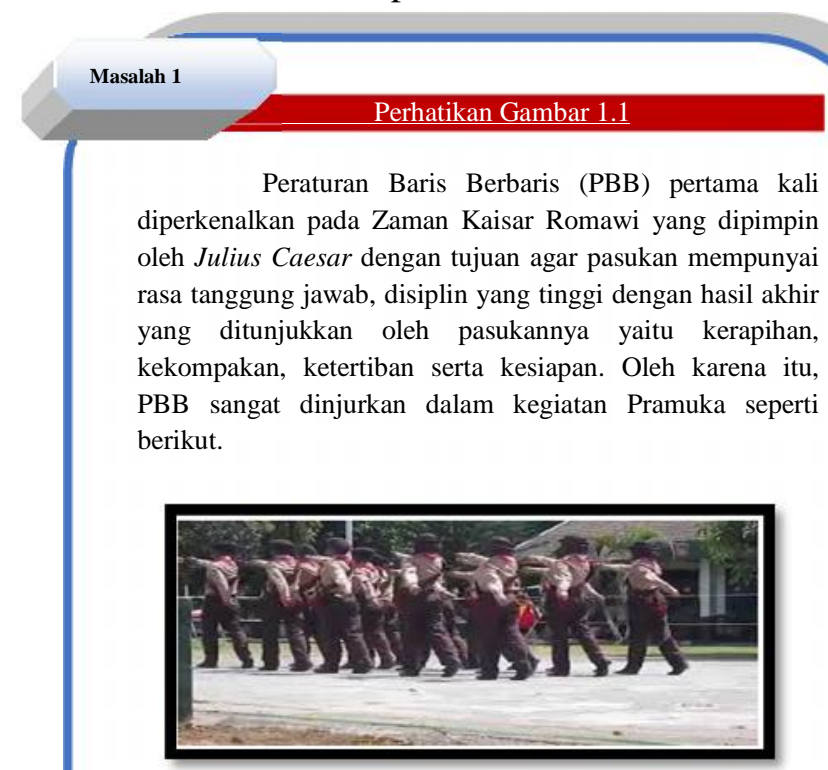

Badu dan teman kelas X-Mia 5 sedang mengikuti kegiatan Ekstrakurikuler vaitu kepramukaan. Mereka sedang 


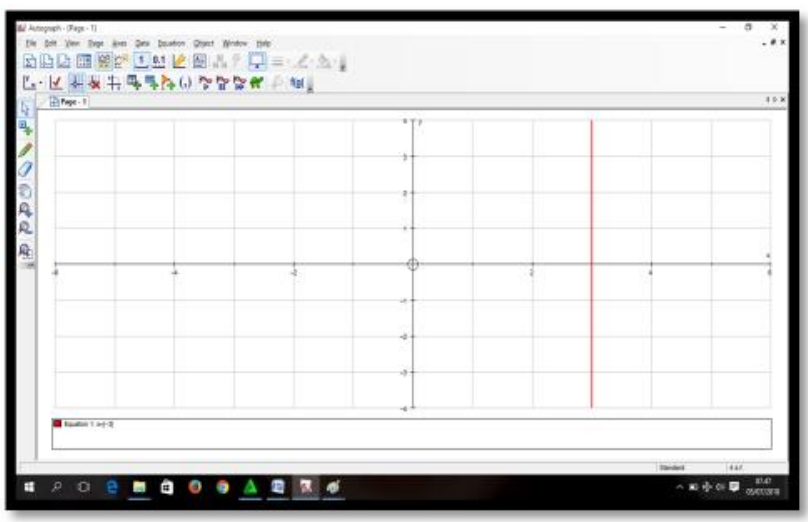

Gambar 4. Solusi Pemecahan Masalah dengan Bantuan Software Autograph

Hal inilah yang mendorong peneliti untuk mengkaji tentang "Perbedaan Kemampuan Pemecahan Masalah Matematis dan Kemandirian Belajar Siswa Melalui Pendekatan Scientific dan Pendekatan Scientific Berbantuan Software Autograph (SBSA)".

\section{KAJIAN TEORITIS}

\section{Kemampuan Pemecahan Masalah Matematis.}

Dalam pembelajaran matematika, suatu pertanyaan akan menjadi masalah hanya jika pertanyaan itu menunjukkan adanya suatu tantangan (challenge) yang tidak dapat dipecahkan oleh prosedur rutin yang sudah diketahui oleh siswa. Menurut Nakin (2003:89) bahwa "pemecahan masalah merupakan proses yang menggunakan langkah-langkah tertentu (heuristik) yang membantu dalam menyelesaikan masalah". NCTM (2000:1) menyatakan "pemecahan masalah mengacu pada tugas matematika yang memiliki potensi untuk memberikan tantangan intelektual dan meningkatkan pemahaman pengembangan matematika siswa".

Charles, Lester, dan O'Daffer (Szetela dan Nicol, 1982:2) menyusun indikator dari setiap aspek atau tahap pemecahan masalah yang lebih praktis dari kedua indikator diatas yaitu: (1) Memahami Masalah (Understanding Problem), (2) Merencanakan Pemecahan Masalah (Solving the Problem), dan (3) Menyelesaikan Masalah (Answer the Problem), seperti pada Tabel 1 berikut.
Tabel 1. Indikator Kemampuan Pemecahan Masalah Matematis

\begin{tabular}{rl|l}
\hline No & $\begin{array}{l}\text { Aspek } \\
\text { Kemampuan } \\
\text { Pemecahan } \\
\text { Masalah }\end{array}$ & \multicolumn{1}{c}{$\begin{array}{c}\text { Indikator } \\
\text { Pencapaian }\end{array}$} \\
\hline 1 & $\begin{array}{l}\text { Memahami } \\
\text { Masalah } \\
\text { (Understanding } \\
\text { Problem) }\end{array}$ & $\begin{array}{l}\text { Memahami } \\
\text { masalah dengan } \\
\text { tuntas }\end{array}$ \\
\hline 2 & $\begin{array}{l}\text { Merencanakan } \\
\text { pemecahan masalah } \\
\text { Solving } \\
\text { problem) }\end{array}$ & $\begin{array}{l}\text { Memilih strategi } \\
\text { yang cocok dengan } \\
\text { merumuskan } \\
\text { rencana yang bisa } \\
\text { menghasilkan } \\
\text { solusi yang benar } \\
\text { tanpa kesalahan } \\
\text { aritmetika }\end{array}$ \\
& & $\begin{array}{l}\text { Menerapkan } \\
\text { konsep matematis, } \\
\text { melakukan } \\
\text { perhitungan } \\
\text { dengan tepat. }\end{array}$ \\
\hline 3 & $\begin{array}{l}\text { Menyelesaikan } \\
\text { Masalah (Answe } \\
\text { the problem) }\end{array}$ & \\
\end{tabular}

Tabel 2. Rubrik Skala Penilaian Indikator Kemampuan Pemecahan Masalah Matematis

\begin{tabular}{cl|l}
\hline No & $\begin{array}{l}\text { Aspek } \\
\text { Kemampuan } \\
\text { Pemecahan } \\
\text { Masalah }\end{array}$ & \multicolumn{1}{c}{$\begin{array}{c}\text { Indikator } \\
\text { Pencapaian }\end{array}$} \\
\hline 1 & $\begin{array}{l}\text { Memahami } \\
\text { Masalah } \\
\text { (Understanding } \\
\text { Problem) }\end{array}$ & $\begin{array}{l}\text { Memahami } \\
\text { masalah dengan } \\
\text { tuntas }\end{array}$ \\
\hline 2 & $\begin{array}{l}\text { Merencanakan } \\
\text { pemecahan masalah } \\
\text { (Solving } \\
\text { problem) }\end{array}$ & $\begin{array}{l}\text { Memilih strategi } \\
\text { yang cocok dengan } \\
\text { merumuskan } \\
\text { rencana yang bisa } \\
\text { menghasilkan } \\
\text { solusi yang benar } \\
\text { tanpa kesalahan } \\
\text { aritmetika }\end{array}$ \\
& & $\begin{array}{l}\text { Menerapkan } \\
\text { konsep matematis, } \\
\text { melakukan } \\
\text { perhitungan } \\
\text { dengan tepat. }\end{array}$ \\
\hline 3 & $\begin{array}{l}\text { Menyelesaikan } \\
\text { Masalah (Answer } \\
\text { the problem) }\end{array}$ &
\end{tabular}


Vol. 13, No. 1, Juni 2020

Sumber: Charles, Lester, dan 0'Daffer (Szetela dan Nicol, 1982:2)

\section{Kemandirian Belajar}

Kemandirian belajar sebagian besar dari pengaruh pemikiran sendiri, perasaaan, strategi, dan perilaku yang diorientasikan ke arah pencapaian tujuan belajar. Menurut Zimmerman (2008:166) mengungkapkan "kemandirian belajar merupakan suatu proses proaktif siswa untuk memperoleh keterampilan akademis, seperti: menetapkan tujuan, memilih, dan melakukan pembelajaran melalui efektivitas diri dan tingkatan aspek metakognitif, motivasi dan tingkah laku siswa ketika aktif berpartisipasi dalam proses pembelajaran mereka sendiri”. Selain itu, Zumbrunn, Taslock \& Roberts (2011:4) menyatakan "kemandirian belajar merupakan suatu proses yang membantu siswa dalam mengelola pikiran, perilaku, dan emosi sendiri agar berhasil mengarahkan pengalaman belajar".

Menurut Winne dan Perry (2000:546) mengatakan "Self-Regulated Learning Interview Schedule (SRLIS). The SRLIS was developed by Zimmerman and Martin-Pons $(1886,1988: 825)$ to explore SRL among high school student", artinya untuk mengukur kemandirian belajar Siswa SMA dengan mengunakan Self-Regulated Learning Interview Schedule (SRLIS) telah dikembangkan oleh Zimmerman dan Martin-Pons (1886, 1988:285). Menurut Zumbrunn, Taslock \& Roberts (2011:4) mengemukakan "indikator kemandirian belajar, yaitu 1) pemikiran dan perencanaan, 2) pengontrolan belajar, dan 3) refleksi hasil belajar". Selain itu, menurut Lestari dan Yudhanegara (2015:94-95) menyatakan "adapun beberapa indikator yang dapat digunakan untuk mengukur kemandirian belajar adalah sebagai berikut: 1) inisiatif belajar, 2) memiliki kemampuan menentukan nasib sendiri, 3) mendiagnosis kebutuhan belajar, 4) kreatif dan inisiatif dalam memanfaatkan sumber belajar dan memilih strategi belajar, 5) memonitor, mengatur, dan mengontrol belajar, 6) mampu menahan diri, 7) membuat keputusan-keputusan sendiri, dan 8) mampu mengatasi masalah".

Adapun indikator kemandirian belajar yang digunakan dalam penelitian ini yaitu modifikasi Zimmerman (1988:287) yaitu: 1) Evaluasi terhadap kemajuan tugas (self evaluating), 2) Mengatur materi pelajaran (organizing and transforming), 3) Membuat rencana dan tujuan belajar (goal setting and planning), 4) Mencari informasi (seeking information), 5) Mengatur lingkungan belajar (enviromental structuring), 6) Mengulang dan mengingat (rehearsing and memorizing), 7) Meminta bantuan teman, guru, orang dewasa (seeking peer, teacher, adult assistence), dan 8) Mengulang tugas/ tes sebelumnya (review test/work).

\section{Pendekatan Scientific}

Pendekatan scientific adalah konsep dasar yang mewadahi, menginspirasi, menguatan, dan melatari pemikiran tentang bagaimana metode pembelajaran diterapkan berdasarkan teori tertentu. "National Science Teacher Association (NSTA) mendefinisikan pendekatan scientific sebagai belajar (mengajar) sains dan teknologi dalam konteks pengalaman manusia" (Daryanto \& Herry, 2014:82).

Abidin (2014:122) mendefinisikan "pendekatan scientific sebagai pendekatan pada proses pembelajaran yang dilakukan untuk memecahkan masalah melalui kegiatan perencangan yang matang, pengumpulan data yang cermat, dan analisis yang teliti untuk menghasilkan sebuah simpulan". Selain itu, Senada dengan itu, menurut Daryanto (2014:51) mengungkapkan sebagai berikut: "Pendekatan scientific dirancang sedemikian rupa sehingga peserta didik secara aktif mengkonstruk konsep, hukum atau prinsip melalui tahapan-tahapan mengamati untuk mengidentifikasi atau menemukan masalah, merumuskan masalah, mengajukan atau merumuskan hipotesis, mengumpulkan data dengan berbagai teknik, menganalisis data, menarik kesimpulan dan mengkomunikasikan konsep, hukum, atau prinsip yang ditemukan".

Adapun langkah-langkah pendekatan scientific dalam pembelajaran menurut Daryanto (2014:59) antara lain "mengamati (observasi), menanya, mengumpulkan informasi, mengasosiasi/mengolah informasi/menalar, menarik kesimpulan, dan mengkomunikasikan". Selanjutnya Abidin (2014:141) mengatakan:

Ada empat tahapan dalam pendekatan scientific yang meliputi:

a. Identifikasi masalah

Pembelajaran diawali dengan masalah kemudian dirumuskan dalam pertanyaanpertanyaan (rumusan masalah) oleh peserta didik. Rumusan masalah merupakan pertanyaan pemandu pembelajaran yang harus peserta didik dapatkan jawabannya setelah selesai melaksanakan seluruh rangkaian pembelajaran.

b. Membuat hipotesis yaitu 
Berdasarkan langkah kerja penelitian ini, dalam konteks model pembelajaran peserta didik harus menggunakan penalarannya baik secara induktif maupun deduktif untuk mampu merumuskan jawaban sementara atas pertanyaan yang diajukan.

c. Mengumpulkan dan menganalisis data

Kegiatan pengumpulan data dapat dilakukan baik secara eksperimen maupun studi lainnya. Hasil pengumpulan data tersebut, selanjutnya diolah dan digunakan untuk menjawab pertanyaan penelitian ataupun untuk membuktikan hipotesis.

d. Menginterpretasi data dan membuat kesimpulan

Kegiatan interpretasi merupakan aktivitas yang dilakukan peserta didik untuk memaknai hasil penelitian sederhana yang telah dilakukannya. Hasil interpretasi adalah simpulan yang dibuat oleh peserta didik dan selanjutnya menjadi pengetahuan yang benarbenar dikonstruksi oleh peserta didik sendiri sehingga diyakini akan meningkatkan tingkat retensi yang lebih tinggi jika dibandingkan dengan yang diperoleh peserta didik melalui kegiatan menyimak penjelasan guru.

Berdasarkan argumen di atas disimpulkan pendekatan scientific merupakan pendekatan pembelajaran yang melibatkan keterampilan proses seperti: mengamati, mengklasifikasi, mengukur, meramalkan, menjelaskan, dan menyimpulkan sehingga suatu masalah dapat diselesaikan.

\section{Software Autograph}

Salah satu software yang dapat digunakan untuk membantu tingkat kreatif dan kemampuan pemecahan masalah siswa adalah dengan menggunakan Autograph. Hal yang sesuai pendapat Karnasih (2008) bahwa: "It is dynamic software where spectacular moving interactive images can be added in the class room, especially when a data-projector is instaleed". Ada 3 hal yang ditawarkan pada software Autograph dalam beberapa dimensi (D) yaitu 1 D untuk memudahkan mempelajari statistik dan probabilitas, 2D untuk memudahkan mempelajari pembuatan grafik, koordinat, transformasi dan bivariat data, dan 3D untuk memudahkan mempelajari grafik, koordinat dan transformasi.

Ketiga program di atas dikelompokkan pada level standard dan level advanced. Level standar, level ini dirancang untuk usia sekitar 1116 tahun, penampilannya sangat sederhana sehingga memudahkan user dalam mengoperasikan Autograph. Sedangkan level Advanced digunakan untuk materi lebih lanjut, seperti termasuk kalkulus, distribusi pada probabilitas dan persamaan dalam bentuk 3D. Autograph dapat membantu guru untuk menjelaskan tentang materi yang diajarkan dengan cepat dan menyenangkan terutama ada penggambaran grafik fungsi.

\section{METODE PENELITIAN}

Penelitian ini dikategorikan dalam penelitan eksperimen semu, yang dilakukan di SMA Negeri I Medan dengan seluruh siswa kelas X sebagai populasi dan kelas MIA X- MIA $^{5}$ (eksperimen I) dan kelas MIA X- MIA ${ }^{6}$ (eksperimen II) sebagai sampel. Rancangan yang digunakan dalam penelitian ini adalah Sugiyono (2012:165) mengatakan bahwa "penelitian ini menggunakan metode quasi eksperimen dengan menggunakan desain penelitian yaitu One-Short Case Study yakni eksperimen yang yang dilaksanakan pada dua kelompokpada Tabel 3 berikut :

Tabel 3. Desain Penelitian

\begin{tabular}{|c|c|c|c|}
\hline $\begin{array}{c}\text { Kelompo } \\
\mathbf{k} \\
\text { Perlakua } \\
\mathbf{n} \\
\end{array}$ & $\begin{array}{l}\text { Pengelompok } \\
\text { an KAM }\end{array}$ & Perlakuan & Posttest \\
\hline \multirow{3}{*}{$\begin{array}{l}\text { Eksperim } \\
\text { en I }\end{array}$} & Tinggi & $X_{1}$ & \multirow{6}{*}{$\mathrm{O}$} \\
\hline & Sedang & & \\
\hline & Rendah & & \\
\hline \multirow{3}{*}{$\begin{array}{l}\text { Eksperim } \\
\text { en II }\end{array}$} & Tinggi & \multirow[t]{3}{*}{$\mathrm{X}_{2}$} & \\
\hline & Sedang & & \\
\hline & Rendah & & \\
\hline
\end{tabular}

Sumber : Modifikasi Sugiyono (2012:74)

\section{Instrument, Teknik Pengumpulan Data dan Teknik Analisis Data}

Teknik analisis data yang digunakan dalam penelitian ini adalah Analisis statistik deskriptif digunakan untuk melihat proses jawaban tes kemampuan pemecahan masalah matematis siswa dan Analisis statistik inferensial digunakan untuk menguji hipotesis penelitian. Data yang diperoleh dari skor kemampuan pemecahan masalah matematis dan kemandirian belajar siswa dikelompokkan menurut kelompok pembelajaran (kooperatif dan kontekstual) secara heterogen. 
Pengolahan data dalam pengujian hipotesis diawali dengan menguji prasyarat statistik yang diperlukan, yaitu uji normalitas dan uji homogenitas varians. Selanjutnya dilakukan analisis varians (ANAVA) dua jalur. Seluruh perhitungan statistik menggunakan bantuan program komputer SPSS. 24 dan program Microsoft Excel.

\section{HASIL PENELITIAN}

\section{Deskripsi Kemampuan Awal Matematis} (KAM) Siswa

Kemampuan awal matematis (KAM) adalah pengetahuan yang dimiliki siswa sebelum pembelajaran berlangsung.

\section{Hasil Post Test Kemampuan Pemecahan Masalah Matematis Siswa}

Dari hasil post test kemampuan pemecahan masalah matematis siswa dideskripsikan dalam Tabel 5 sebagai berikut:

Tabel 5. Deskripsi Post Test Berdasarkan KAM

\begin{tabular}{l|lr}
\hline KAM & $\begin{array}{l}\text { Kelas } \\
\text { Eksperimen I }\end{array}$ & \multicolumn{2}{l}{$\begin{array}{l}\text { Kelas } \\
\text { Eksperimen II }\end{array}$} \\
\hline Tinggi & 98,21 & 97,71 \\
\hline Sedang & 80,91 & 62,26 \\
\hline Rendah & 43,00 & 50,73 \\
\hline
\end{tabular}

Tabel 6. Post Test Berdasarkan Tahap Kemampuan Pemecahan Masalah

\begin{tabular}{lll}
\hline Indikator & $\begin{array}{l}\text { Kelas } \\
\text { Eksperimen I }\end{array}$ & $\begin{array}{l}\text { Kelas } \\
\text { Eksperimen II }\end{array}$ \\
\hline Indikator I & 79,96 & 77,02 \\
& & \\
\hline
\end{tabular}

Indikator II

$75,74 \quad 76,29$

Indikator III

$86,76 \quad 84,19$

\section{Kemandirian Belajar Siswa Setelah diberi Perlakuan}

Adapun kemandirian belajar siswa memiliki kisi-kisi termuat pada Tabel 7 berikut.

Tabel 7. Kisi-Kisi Instrumen Angket Skala Self-Regulated Learning

\begin{tabular}{ccc}
\hline No & Indikator & Jumlah \\
\hline 1 & Evaluasi terhadap kemajuan & 4 \\
\hline
\end{tabular}

tugas (self evaluating)

\begin{tabular}{clc}
\hline 2 & $\begin{array}{l}\text { Mengatur materi pelajaran } \\
\text { (organizing and } \\
\text { transforming) }\end{array}$ & 4 \\
\hline 3 & $\begin{array}{l}\text { Membuat rencana dan tujuan } \\
\text { belajar (goal setting and } \\
\text { planning) }\end{array}$ & 4 \\
\hline 4 & $\begin{array}{l}\text { Mencari informasi (seeking } \\
\text { information) }\end{array}$ & 4 \\
\hline 5 & $\begin{array}{l}\text { Mengatur lingkungan belajar } \\
\text { (enviromental structuring) }\end{array}$ & 4 \\
\hline 6 & $\begin{array}{l}\text { Mengulang dan mengingat } \\
\text { (rehearsing and memorizing) }\end{array}$ & 4 \\
\hline 7 & $\begin{array}{l}\text { Meminta bantuan teman, } \\
\text { guru, orang dewasa (seeking } \\
\text { peer, teacher, adult } \\
\text { assistence) }\end{array}$ \\
\hline 8 & $\begin{array}{l}\text { Mengulang tugas/ tes } \\
\text { sebelumnya (review } \\
\text { test/work) }\end{array}$ \\
\hline
\end{tabular}

Sumber: Modifikasi Zimmerman (1988:287)

Adapun hasil kemandirian belajar siswa setelah diberi perlakuan dideskripsikan pada Tabel 7 dan Tabel 8 berikut:

Tabel 8. Rata-rata Indikator Kemandirian Belajar

\begin{tabular}{lcc}
\multicolumn{1}{|c}{ Indikator } & $\begin{array}{c}\text { Kelas } \\
\text { Eksperimen } \\
\text { I }\end{array}$ & $\begin{array}{c}\text { Kelas } \\
\text { Eksperimen } \\
\text { II }\end{array}$ \\
\hline Indikator 1 & 57,55 & 56,60 \\
\hline Indikator II & 50,81 & 47,07 \\
\hline Indikator III & 53,96 & 53,13 \\
\hline Indikator IV & 67,60 & 64,94 \\
\hline Indikator V & 39,44 & 39,34 \\
\hline Indikator VI & 52,47 & 56,34 \\
\hline Indikator VII & 49,83 & 53,78 \\
\hline Indikator VIII & 66,37 & 71,67 \\
\hline
\end{tabular}

Berdasarkan Tabel $7 \&$ Tabel 8 dianalisis bahwa: indikator I kelas eksperimen lebih tinggi

Perbedaan Kemampuan Pemecahan Masalah Matematis dan Kemandirian Belajar Siswa Melalui Pendekatan Scientific dan Pendekatan Scientific Berbantuan Software Autograph 
dari kelas eksperimen II dengan besar perbedaan yaitu 0,95 artinya siswa mampu mengevaluasi terhadap kemajuan tugas (self evaluating) meningkat akibat pendekatan scientific berbantuan software Autograph. Pada Indikator II kelas eksperimen I lebih tinggi dari kelas eksperimen II dengan besar perbedaan rata-rata yaitu 3,74 yang berarti siswa mampu mengatur materi pelajaran (organizing and transforming) meningkat akibat pendekatan scientific berbantuan software Autograph. Indikator III di kelas eksperimen I lebih tinggi dari kelas eksperimen II dengan besar perbedaan rata-rata yaitu 0,83 yang berarti siswa mampu membuat rencana dan tujuan belajar (goal setting and planning) meningkat akibat pendekatan scientific berbantuan software Autograph. Indikator IV di kelas eksperimen I lebih tinggi dari kelas eksperimen II dengan besar perbedaan rata-rata yaitu 2,66 yang berarti siswa mampu mencari informasi (seeking information) meningkat akibat pendekatan scientific berbantuan software Autograph. Indikator $\mathrm{V}$ di kelas eksperimen I lebih tinggi dari kelas eksperimen II dengan besar perbedaan rata-rata yaitu 0,10 yang berarti siswa mampu mengatur lingkungan belajar (enviromental structuring) meningkat akibat pendekatan scientific berbantuan software Autograph.

Untuk indikator VI di kelas eksperimen I lebih rendah dari kelas eksperimen II dengan besar perbedaan rata-rata yaitu 3,87 yang berarti siswa tidak mengulang dan mengingat (rehearsing and memorizing) hal ini untuk pelajaran yang perlu hapalan akibat pendekatan scientific berbantuan software Autograph bukan untuk hapalan melainkan meningkatkan mencari tahu lebih lagi informasi dan membuktikan kebenaran materi dengan bantuan Autograph. Indikator VII di kelas eksperimen I lebih rendah dari kelas eksperimen II dengan besar perbedaan rata-rata yaitu 3,95 yang berarti siswa tidak meminta bantuan teman, guru, orang dewasa (seeking peer, teacher, adult assistence) akibat pendekatan scientific berbantuan software Autograph yang menjadikan siswa lebih mandiri dan tidak membutuhkan bimbingan guru lagi dalam menyelesaikan masalah matematis tetapi dengan bantuan Autograph. Indikator VIII di kelas eksperimen I lebih rendah dari kelas eksperimen II dengan besar perbedaan rata-rata yaitu 5,30 yang berarti siswa tidak mengulang tugas/ tes sebelumnya (review test/work) akibat pendekatan scientific berbantuan software Autograph hanya terbatas pada materi tertentu dalam menyelesaikan masalah matematis seperti dalam materi persamaan dan pertidaan nilai mutlak linear satu variabel dapat menggunakan software Autograph Pengujian Hipotesis 1 dan 3

Kriteria pengujian untuk menguji hipotesis adalah jika $\mathrm{F}_{0}>\mathrm{F}_{\text {tabel }}$ maka tolak $\mathrm{H}_{0}$ dan terima Ha. Adapun hasil uji hipotesis yang pertama dengan uji ANAVA Dua Jalur dideskripsikan pada Tabel 9 berikut

Pada Tabel. 8 menunjukkan interpretasi hasil uji Hipotesis 1 dan Hipotesis 3 melalui uji statistik secara inferensial dengan Anava 2 jalur sebagai berikut:

a. Perbedaan Antara A

$\mathrm{F}(\mathrm{A})$ hitung $>\mathrm{F}(\mathrm{A}) \mathrm{tab}=6,150>3,9840$ maka Ho ditolak dengan kesimpulan bahwa pada taraf kepercayaan $95 \%$ terdapat perbedaan antara kemampuan pemecahan masalah matematis siswa yang memperoleh pendekatan scientific berbantuan software Autograph dengan siswa yang memperoleh pendekatan scientific. Adapun besar pengaruh pendekatan pembelajaran = 0,0704 , berarti pendekatan pembelajaran dapat menjelaskan $7,04 \%$ variansi skor kemampuan pemecahan masalah matematis.

\section{b. Perbedaan Antara B}

$\mathrm{F}(\mathrm{A})$ hitung $>\mathrm{F}(\mathrm{A})$ tabel $=23,882>3,1338$ maka Ho ditolak dengan kesimpulan bahwa pada taraf kepercayaan $95 \%$ terdapat perbedaan antara kemampuan pemecahan masalah matematis antara siswa yang memiliki KAM kategori tinggi, sedang dan rendah. Adapun besar pengaruh KAM = 0,4023 yang berarti KAM dapat menjelaskan $40,23 \%$ variansi skor kemampuan pemecahan masalah matematis.

c. $\quad \mathrm{F}(\mathrm{A} \times \mathrm{B})$ hitung $<\mathrm{F}(\mathrm{A} \times \mathrm{B})$ tabel $=3,119$ $<3,1338$ maka Ho diterima dengan kesimpulan bahwa pada taraf kepercayaan $95 \%$ tidak terdapat interaksi faktor pendekatan pembelajaran dan faktor KAM terhadap kemampuan pemecahan masalah matematis. Adapun besar pengaruh tidak terdapat interaksi antara pendekatan pembelajaran dan $\mathrm{KAM}=0,0587$, yang berarti tidak terdapat interaksi pendekatan pembelajaran dan KAM dapat menjelaskan 5,87\% variasi skor kemampuan pemecahan masalah matematis siswa.

Adapun hasil interpretasi uji Hipotesis 3 menggambarkan tidak terdapat interaksi, dimana setiap garis kategori KAM tidak berpotongan antara KAM tinggi, KAM Sedang dan KAM Rendah 


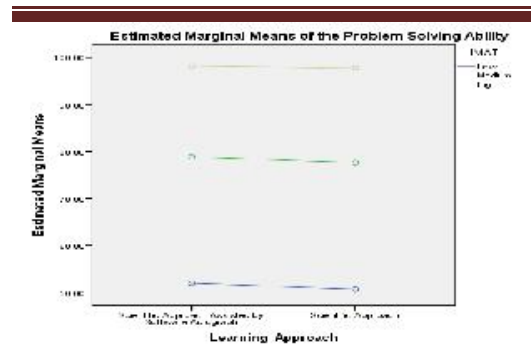

Gambar 5. Interaksi Antara Pendekatan Pembelajaran dan KAM Terhadap Kemampuan Pemecahan Masalah Matematis Siswa

\section{Pengujian Hipotesis 2 dan 4}

Adapun hasil uji hipotesis yang pertama dengan uji ANAVA Dua Jalur

Berdasarkan data perhitungan menunjukkan interpretasi hasil uji Hipotesis 2 dan Hipotesis 4 melalui uji statistik Anava 2 jalur sebagai berikut:

a. Perbedaan Antara A

$\mathrm{F}(\mathrm{A})$ hitung > F(A) tab $=5,914>3,9840$ maka Ho ditolak dengan kesimpulan bahwa pada taraf kepercayaan $95 \%$ terdapat perbedaan antara kemandirian belajar siswa yang memperoleh pendekatan scientific berbantuan software Autograph dengan siswa yang memperoleh pendekatan scientific. Adapun besar efek pendekatan pembelajaran $=0,0674$ berarti pendekatan pembelajaran dapat menjelaskan $6,74 \%$ variansi skor kemandirian belajar siswa.

b. Perbedaan Antara B

$\mathrm{F}(\mathrm{A})$ hitung $>\mathrm{F}(\mathrm{A})$ tab $=110,843>3,1338$ maka Ho ditolak dengan kesimpulan bahwa pada taraf kepercayaan $95 \%$ terdapat perbedaan antara kemandirian belajar antara siswa yang memiliki KAM kategori tinggi, sedang dan rendah. Adapun besar pengaruh $\mathrm{KAM}=0,7636$ yang berarti $\mathrm{KAM}$ dapat menjelaskan $70,36 \%$ variansi skor kemandirian belajar siswa.

c. $\quad \mathrm{F}(\mathrm{A} \times \mathrm{B})$ hitung $<\mathrm{F}(\mathrm{A} \times \mathrm{B})$ tab $=2,630<$ 3,1338 maka Ho diterima dengan kesimpulan bahwa pada taraf kepercayaan $95 \%$ tidak terdapat interaksi faktor pendekatan pembelajaran dan faktor KAM terhadap kemandirian belajar siswa. Adapun besar pengaruh tidak terdapat interaksi antara pendekatan pembelajaran dan $\mathrm{KAM}=0,0457$ berarti tidak terdapat interaksi pendekatan pembelajaran dan KAM dapat menjelaskan $4,57 \%$ variasi skor kemandirian belajar siswa.

Hasil uji Hipotesis 4 untuk interaksi antara Pembelajaran *KAM diperoleh 0,962>0,05 maka $\mathrm{H}_{0}$ diterima dengan kesimpulan bahwa pada taraf kepercayaan $95 \%$ tidak terdapat interaksi faktor model pendekatan pembelajaran dan faktor KAM terhadap kemandirian belajar siswa. Ada hasil uji
Hipotesis 4 yaitu tidak terdapat interaksi dengan grafik antara kelompok KAM (Tinggi, Sedang dan rendah) tidak berpotongan satu sama lain seperti Gambar berikut:

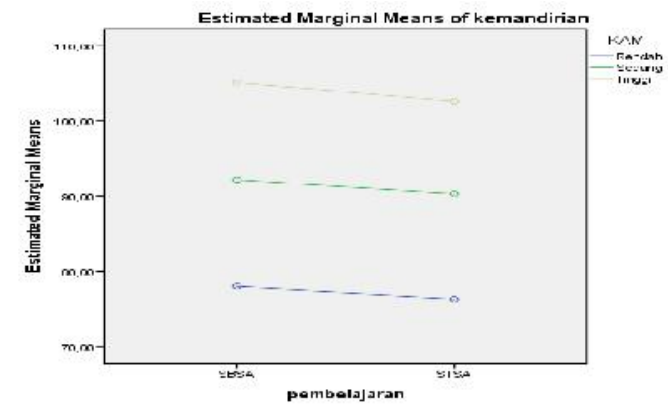

Gambar 6. Interaksi Antara Pendekatan Pembelajaran dan KAM Terhadap Kemandirian Belajar Siswa

\section{PEMBAHASAN}

Sesuai dengan hasil penelitian yang telah diperoleh dan dianalisis, selanjutnya akan dilihat hubungannya dengan tujuan yang telah ditetapkan dalam penelitian ini. Adapun dalam pembahasan ini akan mengkaji mengenai bagaimana tercapainya tujuan peneliti, menafsirkan temuantemuan penelitian, membandingkan dengan penelitian relevan sebelumnya dan menjelaskan hasil penelitian yang mencakup antara lain: kemampuan pemecahan masalah matematis, dan kemandirian belajar, interaksi antara pendekatan pembelajaran dan KAM terhadap kemampuan pemecahan masalah matematis dan interaksi antara pendekatan pembelajaran dan KAM terhadap kemandirian belajar siswa berikut

\section{Kemampuan Pemecahan Masalah Matematis}

Pemecahan masalah matematis dalam penelitian ini merupakan kemampuan siswa berdasarkan aspek-aspek pemecahan masalah, yaitu: 1) Memahami masalah (understanding problem), 2) Merencanakan permasalahan (solving the problem), dan 3) Menyelesaikan masalah (answer the problem). Kemampuan pemecahan masalah matematis siswa selanjutnya dianalisis untuk melihat perbedaan kemampuan siswa di kelas pendekatan scientific berbantuan Autograph dan kemampuan siswa di kelas pendekatan scientific.

Berdasarkan hasil analisis statistik inferensial dengan Anava dua jalur menunjukkan bahwa pada taraf kepercayaan 95\% terdapat perbedaan antara kemampuan pemecahan masalah matematis siswa yang memperoleh pendekatan scientific berbantuan software Autograph dengan 
siswa yang memperoleh pendekatan scientific. Adapun besar pengaruh pendekatan pembelajaran $=0,0704$, berarti pendekatan pembelajaran menjelaskan $7,04 \%$ variansi skor kemampuan pemecahan masalah matematis. Adapun hasil penelitian ini diperkuat oleh penelitian relevan antara lain: hasil penelitian oleh Sudirman, Fatimah \& Jupri. (2017:254) bahwa: pembelajaran ilmiah (Scientific Learning) melalui strategi pembelajaran kuantum yang diterapkan pada pembelajaran matematika di kelas XI SMA 14 Bandung dapat mengoptimalkan kemampuan belajar siswa, sehingga siswa mampu membentuk kemampuan pemecahan masalah mereka dan Self Regulated Learning agar memperoleh hasil belajar matematika yang optimal dan dapat mencapai tujuan pembelajaran sesuai keinginan.

Selanjutnya, hasil penelitian Nufus dan Muhammad (2018:369) dilakukan di SMP IT Almarkazul Islami dan MTSS Misbahul Ulum pada materi SPLDV diperoleh hasil penelitian yaitu "perbedaan peningkatan kemampuan koneksi matematika antara siswa yang diberi model pembelajaran CPS berbantuan Autograph dibandingkan dengan siswa yang diberi model pembelajaran biasa". Begitu juga hasil penelitian Riski, Mulyono, \& Minarni (2018) terhadap 36 siswa VII SMP N 2 Beringin Deli Serdang yaitu: (1) peningkatan pemecahan masalah matematis siswa di kelas pendekatan pendidikan realistis matematika berbasis bantuan Autograph lebih tinggi daripada di kelas konvensional, 2) Proses pemecahan masalah matematika yang dilakukan oleh siswa di kelas pendekatan pendidikan realistis matematika berbasis bantuan Autograph lebih baik daripada siswa di kelas konvensional, hal ini berarti siswa di kelas pendekatan realistis matematika berbasis bantuan Autograph menunjukkan langkah pemecahan masalah yang lebih sistematis dan terarah.

\footnotetext{
Adapun hasil perbandingan analisis $F_{\text {hit } n}$ bahwa pendekatan scientific dengan Autograph lebih unggul dari creative problem solving berbantuan software Autograph yaitu 116,033 lebih tinggi dari 18,854 serta pendekatan scientific berbantuan Autograph lebih unggul dibandingakan realistis matematika berbasis bantuan Autograph yaitu 116,033 lebih tinggi dari 5,514. Adapun analisis hasil penelitian scientific berbantuan Autograph dibandingankan dengan penelitian Suci, Karomah dan Cahyono (2017:259) yang dilakukan di kelas VIII SMP Negeri 15 Semarang dalam mengukur
}

kemampuan pemecahan masalah ditinjau dari selfefficacy siswa dalam implementasi model pembelajaran Arias berpendekatan saintifik menunjukkan bahwa "model pembelajaran ARIAS berpendekatan saintifik efektif terhadap kemampuan pemecahan masalah berdasarkan rata-rata skor kemampuan pemecahan masalah matematika siswa yang diajar dengan model ARIAS berpendekatan saintifik mencapai nilai ketuntasan adalah 75,65". Sedangkan dalam penelitian ini rata-rata skor kemampuan pemecahan masalah dengan scientifc berbantuan software Autograph mencapai nilai ketuntasan 78,90 . Hal ini menunjukkan keunggulan dalam penelitian ini scientifc berbantuan software Autograph lebih efektif dalam meningkatkan rata-rata skor kemampuan pemecahan masalah dari pada model ARIAS.

Berdasarkan penyusunan perangkat pembelajaran scientific untuk meningkatkan kemampuan pemecahan masalah, hasil validasi perangkat penelitian scientific berbantuan Autograph lebih baik dibandingkankan dengan hasil penelitian Yustitia (2015:49) dengan ujicoba penelitian ini dilakukan di kelas VIII SMP N 4 Taman. Hasil validasi perangkat pembelajaran penelitian Yustitia dinyatakan valid menurut ahli karena diperoleh rata-rata validasi yaitu 3,42 . Sedangkan hasil validasi perangkat scientifc berbantuan software Autograph dalam penelitian ini diperoleh rata-rata validasi oleh ahli validator yaitu 4,54.

Berdasarkan uji statistik dan hasil analisis perbandingan berbagai penelitian relevan disimpulkan bahwa: hasil penelitian pendekatan scientific berbantuan software Autograph lebih unggul dan efektif dalam meningkatkan kemampuan pemecahan masalah. Salah satu faktor penyebab lebih baiknya pendekatan scientific berbantuan software Autograph terhadap kemampuan pemecahan masalah matematis adalah penggunaan software Autograph yang mampu: 1) Mempengaruhi proses kerja dan meningkatkan produksi, khususnya dengan meningkatkan kecepatan dan efesiensi proses, dan meningkatkan akurasi penyajian hasil, dengan demikian berkontribusi terhadap kecepatan dan produktivitas pelajaran, 2) Memungkinkan siswa untuk menvisualisasikan dan lebih memahami matematika dalam kehidupan nyata yang sangat berkontribusi dalam pemecahan masalah, 3) Mengatasi kesulitan siswa dan mengkontruksi gambar, termasuk melewati masalah yang dihadapi oleh siswa ketika menulis dan menggambar dengan tangan dan menfasilitasi 
koreksi kesalahan, sehingga meningkatkan rasa kemampuan dan kemandirian siswa dalam melaksanakan tugas pembelajaran yang diberikan termasuk dalam soal pemecahan masalah matematis, 4) Pengajaran dengan mengintegrasikan Autograph di sekolah dapat meningkatkan efektifitas dan kualitas mengajar, 5) Meningkatkan variasi dan daya tarik aktivitas di kelas, khususnya variasi format pembelajaran dan merubah suasana dengan memperkenalkan unsur bermain, menyenangkan, mengembirakan, dan mempermudah tugas yang sulit. 6) Mengembangkan kebebasan siswa dan pertukaran kelompok sebaya, khususnya menyediakan kesempatan bagi siswa untuk latihan mandiri lebih banyak dan bertanggung jawab, berbagi keahlian dan saling mendukung dalam memecahkan soal dan pemecahan masalah dalam LAS, 7) Membantu guru dalam membuat lebih memperhatikan papan tulis bertindak interaktif dan bertindak sebagai media interaksi antara siswa atau antara guru serta 8) Mampu menguatkan konsep.

\section{Kemandirian Belajar Siswa}

Kemandirian belajar merupakan salah satu afektif yang sangat penting untuk dilatih oleh siswa, seperti: menetapkan tujuan, memilih, dan melakukan pembelajaran melalui efektivitas diri dan tingkatan aspek metakognitif, motivasi dan tingkah laku siswa ketika aktif berpartisipasi dalam proses pembelajaran mereka sendiri.

Adapun hasil analisis statistik inferensial dengan Anava dua jalur menunjukkan bahwa pada taraf kepercayaan $95 \%$ terdapat perbedaan antara kemampuan pemecahan masalah matematis siswa yang memperoleh pendekatan scientific berbantuan software Autograph dengan siswa yang memperoleh pendekatan scientific dengan besar pengaruh penndekatan pembelajaran $=0$, 0704, yang berarti pendekatan pembelajaran dapat menjelaskan 7,04\% variansi skor kemampuan pemecahan masalah matematis. $\mathrm{Hal}$ ini menunjukkan pendekatan scientific berbantuan software Autograph memiliki pengaruh yang lebih besar dalam mengembangkan kemandirian. Ini disebabkan beberapa hal, salah satunya adalah karakteristik pendekatan scientific berbantuan software Autograph yaitu pembelajaran yang memberi kesempatan pada siswa berpikir secara individual atau berpasangan sehingga siswa dapat memastikan jawaban apa yang dipikirkan dengan bantuan Autograph.

Adapun hasil penelitian ini diperkuat dengan hasil penelitian Paryatun, Usodo \& Retno
(2016) pada siswa kelas X SMA Negeri SeKabupaten Sukoharjo dengan hasil penelitian yaitu "ketiga kategori kemandirian belajar siswa memberikan efek yang tidak sama terhadap prestasi belajar matematika siswa pada materi Dimensi Tiga. Prestasi belajar matematika siswa dengan kemandirian belajar tinggi lebih baik dari siswa dengan kemandirian belajar sedang maupun kemandirian belajar rendah. Untuk prestasi belajar matematika siswa dengan kemandirian belajar sedang lebih baik daripada prestasi belajar matematika siswa dengan kemandirian belajar rendah. Adapun siswa yang mempunyai kemandirian belajar tinggi memiliki prestasi belajar matematika lebih baik daripada siswa yang mempunyai kemandirian belajar sedang maupun rendah".

Hasil penelitian ini diperkuat dengan membandingkan penelitian relevan bahwa pendekatan scientific berbantuan software Autograph lebih baik dari pada penelitian Anim mengenai kemandirian siswa kelas X SMA Negeri 5 Pematang siantar menunjukkan bahwa (1) Terdapat perbedaan kemandirian belajar siswa antara siswa yang memperoleh model pembelajaran inkuiri berbantuan Autograph dengan siswa yang memperoleh model pembelajaran ekspositori berbantuan Autograph dengan perolehan $\mathrm{F}$ hitung secara manual dengan Anava 2 jalur yakni 4,299. Sedangkan untuk hasil $\mathrm{F}$ hitung dengan pendekatan scientific berbantuan software Autograph lebih tinggi yakni 110, 843.

Adapun perbandingan ditinjau dari tingkat reliabelitas angket kemandirian belajar pendekatan scientific berbantuan software Autograph lebih tinggi dengan koefisien reliabilitas sebesar 0,83 (interpretasi reliabilitas tinggi dibandingkan dengan hasil penelitian Mulyana (2015:44) pada 54 siswa kelas IX di satu SMP Negeri di Kabupaten Garut dengan perolehan koefisien reliabilitas sebesar 0,65 (interpretasi reliabilitas sedang).

Simpulan temuan analisis perbandingan dengan penelitisn relevan bahwa kemandirian belajar mempengaruhi hasil belajar dan kemampuan pemecahan masalah dapat dipahami hal ini dikarenakan kemandirian belajar akan mempengaruhi dalam melaksanakan proses belajar mengajar. Didalam kemandirian belajar terdapat tiga aspek yaitu: 1) Aspek kognitif yang berhubungan dengan gejala mengenai pikiran, 2) Aspek afektif, yaitu aspek yang berwujud proses yang menyangkut perasaan-perasaan tertentu 
seperti, ketakutan, kedengkian, simpati, dan antipati yang ditujukan pada objek-objek tertentu, 3) aspek konatif atau psikomotor, yaitu berwujud proses kecenderungan untuk berbuat sesuatu objek. 4) Kemandirian belajar siswa pada pendekatan scientific berbantuan software Autograph tergolong cukup baik. Selain dari itu, terdapat asosiasi kuat antara kemampuan pemecahan masalah matematis dan kemandirian belajar siswa.

\section{Interaksi Pembelajaran Kemampuan $\begin{array}{cr}\text { Antara } & \text { Pendekatan } \\ \text { dan KAM } & \text { terhadap } \\ \text { Pemecahan } & \text { Masalah }\end{array}$ Matematis Siswa}

Interaksi dalam penelitian ini adalah kerja sama antara KAM dan pendekatan yang diterapkan secara bersamaan mempengaruhi kemampuan pemecaham masalah matematis siswa. Adapun hasil analisis statistik dengan Anava dua jalur menunjukkan bahwa antara KAM dengan pendekatan pelajaran menunjukkan: pada taraf kepercayaan 95\% tidak terdapat interaksi faktor pendekatan pembelajaran dan faktor KAM terhadap kemampuan pemecahan masalah matematis dengan arti tidak adanya pengaruh bersama-sama yang disumbangkan oleh pendekatan pembelajaran (pendekatan scientific berbantuan software Autograph dan pendekatan scientific) dengan KAM (tinggi, rendah, sedang) siswa terhadap kemampuan pemecahan masalah matematis siswa.

Hasil penelitian ini diperkuat dengan hasil penelitian Adriani (2017:1) bahwa: "tidak ada pengaruh secara bersama-sama antara pendekatan yang diterapkan dengan KAM siswa terhadap terjadinya peningkatan kemampuan pemecahan masalah matematis siswa dengan hasil analisis data menunjukkan nilai signifikansi sebesar 0,211. Begitu juga hasil penelitian Riski, Mulyono, \& Minarni (2018) terhadap 36 siswa VII SMPN 2 Beringin Deli Serdang yaitu: hasil uji interaksi antara faktor pembelajaran dan faktor KAM dilakukan dengan menggunakan Anava dua arah sebesar 0,902 menunjukkan bahwa tidak ada interaksi yang signifikan antara faktor pendekatan pembelajaran dan faktor KAM terhadap peningkatan kemampuan pemecahan masalah. Artinya, tidak ada efek simultan antara pendekatan pembelajaran dan KAM terhadap peningkatan kemampuan pemecahan masalah matematis. Adapun hasil uji pendekatan pembelajaran*KAM lebih tinggi dalam penelitian ini menggunakan pendekatan scientific berbantuan software Autograph sebesar 0,985 dengan syarat nilai signifikansi lebih besar dari nilai taraf signifikan 0,05 .

Ada beberapa hal dalam penelitian ini yang menyebabkan tidak terdapatnya interaksi antara pendekatan pembelajaran (pendekatan scientific berbantuan software Autograph dan pendekatan scientific) dengan KAM (tinggi, rendah, sedang) siswa terhadap peningkatan kemampuan pemecahan masalah matematis siswa berkaitan dengan pengelompokan KAM hal ini disebabkan antara lain: (1) pengelompokan KAM siswa peneliti hanya berpedoman pada perolehan nilai siswa pada tes KAM yang diambil dari soal-soal UN yang belum mencerminkan kemampuan pemecahan masalah matematis siswa yang diharapkan, sehingga siswa yang mempunyai KAM tinggi belum tentu berkemampuan pemecahan masalah yang tinggi, siswa yang mempunyai KAM sedang belum tentu berkemampuan pemecahan masalah yang sedang, dan siswa yang mempunyai KAM rendah belum tentu berkemampuan pemecahan masalah yang rendah, (2) Pemilihan sampel random sederhana yang digunakan dalam penelitian sehingga memungkinkan penyebaran variabel-variabel yang tidak dikontrol menjadi tidak merata dalam setiap kelompok sehingga mengakibatkan data hasil penelitian tidak terdapat interaksi antara KAM dan pendekatan pembelajaran terhadap kemampuan pemecahan masalah matematis siswa, dan (3) Faktor lain adalah terkait dengan pendekatan pembelajaran yang diterapkan dengan arti pendekatan pembelajaran pendekatan scientific berbantuan software Autograph dan pendekatan scientific memiliki kesamaan yaitu pendekatan pembelajaran scientific. Namun, yang membedakan dalam eksperimen I mengunakan scientific berbantuan software Autograph berbeda

\section{Interaksi Antara Pendekatan Pembelajaran dan KAM Terhadap Kemandirian Belajar Siswa}

Interaksi dalam penelitian ini adalah kerjasama antara pendekatan pembelajaran dan KAM terhadap kemandirian belajar belajar siswa. Interaksi terjadi manakala suatu KAM dan pendekatan pembelajaran bersama-sama memiliki efek terhadap terjadinya peningkatan kemandirian belajar siswa. Adapun antara KAM dengan pendekatan pelajaran menunjukkan bahwa pada taraf kepercayaan $95 \%$ tidak terdapat interaksi faktor pendekatan pembelajaran dan faktor KAM terhadap kemandirian belajar siswa. Adapun besar

Perbedaan Kemampuan Pemecahan Masalah Matematis dan Kemandirian Belajar Siswa Melalui Pendekatan Scientific dan Pendekatan Scientific Berbantuan Software Autograph 


\section{PARADIKMA JURNAL PENDIDIKAN MATEMATIKA}

Vol. 13, No. 1, Juni 2020

pengaruh tidak terdapat interaksi antara pendekatan pembelajaran dan $\mathrm{KAM}=0,0457$ berarti tidak terdapat interaksi pendekatan pembelajaran dan KAM dapat menjelaskan 4,57\% variasi skor kemandirian belajar siswa. Hal ini menunjukkan bahwa tidak adanya pengaruh bersama-sama yang disumbangkan oleh pendekatan pembelajaran (scientific berbantuan software Autograph dan scientific) dengan KAM (tinggi, rendah, sedang) siswa terhadap kemandirian belajar siswa.

Didukung dari berbagai penelitian relevan bahwa tidak terdapat interaksi pada hasil penelitian oleh Listiana (2015) bahwa pendekatan pembelajaran tidak memberikan pengaruh yang berbeda-beda secara signifikan terhadap peningkatan kemandirian belajar pada tingkat KAM yang rendah, sedang maupun tinggi. Faktor tidak terdapat interaksi dalam penelitiannya karena soal KAM diambil dari soal materi prasyarat sehingga tidak mencerminkan kemampuan yang sebenarnya. Begitu juga hasil penelitian Izzati dan Nur (2012) terhadap 239 orang siswa kelas VII pada tiga SMP Negeri di Kota Bandung dengan penerapan pendekatan realistik, masing-masing mewakili sekolah level KAM (tinggi, sedang, dan rendah). Berdasarkan uji hipotesis penelitian pada taraf signifikansi 5\%, menggunakan Uji-t Berpasangan, Uji Peringkat Bertanda Wilcoxon, Uji-t Independen, Uji MannWhitney, dan Uji GLM Univariate Anova dilanjutkan dengan Uji Post Hoc for Multiple Comparison Bonferroni dan Uji Post Hoc for Multiple Comparison Games-Howell yaitu tidak ada pengaruh interaksi antara pendekatan pembelajaran dan level sekolah serta antara pendekatan pembelajaran dan kategori KAM siswa terhadap peningkatan kemandirian belajar siswa. Hasil analisis bahwa apabila soal tes diambil dari materi prasyarat berarti siswa yang berada pada KAM kategori tinggi akan lebih tinggi pencapaiannya dari pada siswa yang memiliki kategori KAM rendah. Siswa yang berada pada KAM kategori rendah, sudah mengalami kesulitan sehingga kemungkinan besar untuk materi selanjutnya siswa juga akan merasa kesulitan. Oleh karena itu, penelitian tersebut menyebutkan tidak terdapat interaksi. Sebagaimana yang dikatakan Glass \& Hopkins (1996:486-487) bahwa "The absence of interaction is the statistical justification for generalizability" yang artinya tidak terdapat interaksi adalah pembenaran statistika secara umum.
Pendekatan scientific berbantuan software Autograph dan pendekatan scientific memiliki karakterisik kelompok kecil yang memungkinkan terjadinya kerjasama antara anggota kelompok dan guru memberikan motivasi agar siswa memanfaatkan kelompok sebagai sarana berdiskusi dan bertukar pikiran, sehingga yang pada akhirnya dapat mampu mengembangkan kemampuan potensial siswa khususnya bagi siswa kelompok kemampuan matematika sedang dan rendah. Dengan demikian, pendekatan pembelajaran diduga dapat menjadikan salah satu faktor yang menyebabkan tidak terdapatnya interaksi antar pembelajaran dan KAM terhadap kemandirian belajar siswa, Alasan lainnya adalah faktor-faktor yang tidak diikut sertakan dalam penelitian ini yang disebabkan oleh keterbatasan waktu dan biaya seperti faktor minat dan sikap belajar siswa, latar belakang ekonomi keluarga siswa sehingga semata-mata dipengaruhi oleh pendekatan pembelajaran yang diterapkan

\section{KESIMPULAN}

Berdasarkan hasil uji hipotesis dan analisis data penelitian tentang kemampuan pemecahan masalah matematis dan kemandirian belajar siswa yang diajar dengan pendekatan scientific berbantuan software Autograph dan pendekatan scientific maka diperoleh beberapa kesimpulan sebagai berikut:

1. Terdapat perbedaan nyata kemampuan pemecahan masalah matematis siswa yang diberi pendekatan scientific berbantuan software Autograph dan pendekatan scientific dengan efek perbedaan pengaruhnya sebesar 0,4023. Adapun perolehan rata-rata kemampuan pemecahan masalah matematis yang diajarkan dengan pendekatan pendekatan scientific berbantuan software Autograph adalah 79,78 sedangkan rata-rata kelompok yang diajarkan dengan pendekatan pendekatan scientific adalah sebesar 78,31 artinya kemampuan pemecahan masalah siswa dengan pendekatan pendekatan scientific berbantuan software Autograph lebih tinggi dari pendekatan scientific.

2. Tidak terdapat interaksi faktor pendekatan pembelajaran dan faktor KAM terhadap kemampuan pemecahan masalah matematis. Adapun besar pengaruh tidak terdapat interaksi antara pendekatan pembelajaran dan $\mathrm{KAM}=0,0587$, yang berarti tidak terdapat interaksi pendekatan pembelajaran dan KAM dapat menjelaskan $5,87 \%$ variasi skor 
kemampuan pemecahan masalah matematis siswa.

3. Terdapat perbedaan nyata antara kemandirian belajar siswa yang memperoleh pendekatan scientific berbantuan software Autograph dengan siswa yang memperoleh berbantuan software. Adapun besar efek pendekatan pembelajaran $=0,0674$ berarti pendekatan pembelajaran dapat menjelaskan $6,74 \%$ variansi skor kemandirian belajar siswa.

4. Tidak terdapat interaksi faktor pendekatan pembelajaran dan faktor KAM terhadap kemandirian belajar siswa. Adapun besar pengaruh tidak terdapat interaksi antara pendekatan pembelajaran dan $\mathrm{KAM}=0,0457$ berarti tidak terdapat interaksi pendekatan pembelajaran dan KAM dapat menjelaskan $4,57 \%$ variasi skor kemandirian belajar siswa.

\section{UCAPAN TERIMA KASIH}

Pada kesempatan ini, penulis mengucapkan terimakasih kepada:

1. Bapak Prof. Dr. Bornok Sinaga, M.Pd selaku Direktur Program Pascasarjana UNIMED yang telah memberikan kesempatan serta bantuan administrasi selama pendidikan di Universitas Negeri Medan, sekaligus sebagai dosen penguji yang telah memberikan sumbangsih pemikiran konstruktif untuk tesis ini.

2. Bapak Prof. Dr. Edi Syahputra, M.Pd selaku Ketua Prodi Pendidikan Matematika Pascasarjana UNIMED sekaligus sebagai pembimbing II yang telah memberikan masukan kepada penulis dalam penulisan tesis ini.

3. Bapak Dr. Mulyono, M.Si selaku sekretaris Prodi Pendidikan Matematika Pascasarjana UNIMED dan juga sebagai penguji yang telah memberikan banyak kritik, masukan, dan saran perbaikan yang bersifat membangun dalam tesis ini.

4. Ibu Dr. E. Elvis Napitupulu, M.S, selaku Pembimbing I yang telah memberikan arahan dan bimbingan serta motivasi yang sangat bermanfaat dan berharga bagi penulis dalam penyusunan tesis ini sampai dengan selesai.

5. Bapak Dr. Togi, M. Pd dan Bapak Dr. Asrin Lubis, M. Pd penguji yang telah memberikan masukan dan sumbangan pemikiran sehingga menambah wawasan pengetahuan penulis dalam penyempurnaan penulisan tesis ini.

6. Kepada keluarga tercinta Ayahanda Binsar Manalu, Ibunda Marlina Tampubolon,
Adinda Endang Agustina Manalu Saragih, Nurlela Manalu serta Ananda Iwan Lamganda Manalu yang selalu mendo'akan, memberikan motivasi, dukungan moril maupun materil kepada penulis sehingga tesis ini terselesaikan dengan baik.

7. Teman-teman seperjuangan kelas B-3 dan teman-teman Pendidikan Matematika PPs UNIMED 2016 serta segenap pihak yang berpartisipasi membantu penulis dalam menyelesaikan tesis ini yang tidak dapat penulis sebutkan satu persatu.

\section{REFERENSI}

Abidin, Y. 2014. Desain Sistem Pembelajaran dalam Konteks Kurikulum 2013. Bandung: PT Refika Aditama.

Andriani, A. 2017. Interaksi Antara Model Pembelajaran dengan Kemampuan Awal Matematika Terhadap Peningkatan Kemampuan Pemecahan Masalah Matematik Mahasiswa FMIPA Pendidikan Matematika. SEMNASTIKAUNIMED. (Online). ISBN:978-602-17980-9-6.

Afriati, V. \& Saragih, S. 2012. Peningkatan Pemahaman Konsep Grafik Fungsi Trigonometri Siswa SMK melalui Penemuan Terbimbing Berbantuan Software Autograph. Jurnal Pendidikan dan Kebudayaan. Vol 18 No. 4

Amalia, E. Surya, E. Syahputra, E. 2017. The Effectiveness of Using Problem Based Learning (PBL) in Mathematics Problem Solving Ability for Junior High School Students. IJARIIE. (Online). Vol-3 Issue2 2017, diakses 20 November 2017.

Arum, D. R. Riyadi, \& Sri. S. 2014. Analisis Proses Pembelajaran Berbasis Masalah (Problem Based Learning) Matematika Dengan Pendekatan Ilmiah (Scientific Appraoch ) Di SMA Negeri 1 Jogorogo Kelas X Tahun Pelajaran 2013/2014 Kabupaten Ngawi. JMEE. (Online) Vol. IV, No. 2. Diakses 10 Okober 2017.

Banjarnahor, S. Sinaga, B. \& Napitupulu, E. 2017. Analysis of Problem Solving Ability in Applying Problem Based Learning Reviewed From the Learning Style. Journal of Education and Practice. (Online). Vol.8, No.34, 2017.

Daryanto. 2014. Pendekatan Pembelajaran Saintifik Kurikulum 2013. Yoyakarta: Penerbit Gava Media. 
Daryanto. \& Herry S. 2014. Siap Menyongsong Kurikulum 2013. Yogyakarta: Gava Media. Fyfe, E. R \& Johnson, B. R. 2016. The benefits of computer-generated feedback for mathematics problem solving. Journal of Experimental Child Psychology (Elselvier). Volume 147, Pages 140-151.

Glass, G.V. \& Hopkins, K.D. 1996. Statistical Methods in Education and Psychology. USA: A Simon \& Schuster Company.

Hasratuddin. 2015. Mengapa Harus Belajar Matematika. Medan: Perdana Publishing.

Izzati \& Nur. 2012. Peningkatan Kemampuan Komunikasi Matematis Dan Kemandirian Belajar Siswa Smp Melalui Pendekatan Pendidikan Matematika Realistik. Universitas Pendidikan Indonesia.

Kurniasih, I. 2014. Implementasi Kurikulum 2013: teori dan Praktek. Surabaya: Kata Pena.

Karnasih, I. \& Sinaga, M. 2014. Enhancing Mathematical Problem Solving and Mathematical Connection Through the Use of Dynamic Software Autograph in Cooperative Learning Think-Pair-Share. SAINSAB. (Online). Vol. 2 No. 1 (2017diakses 20 November 2017).

Kusmaryono, I. \& Suyitno, H. The Effect of Constructivist Learning Using Scientific Approach on Mathematical Power and Conceptual Understanding of Students Grade IV. 2016. Journal of Physics.

Kusumaningrum, I A. Ashadi, A. \& Indriyanti, N Y. 2017. Scientific Approach and Inquiry Learning Model in the Topicof Buffer Solution: A Content Analysis. International Conference on Mathematics and Science Education (ICMSCE).

Laili, H. 2016. Pengaruh Model Pembelajaran Contextual Teaching and Learning (CTL) Dalam Meningkatkan Kemampuan Pemecahan Masalah Matematika Siswa MTs Nurul Hakim Kediri Ditinjau dari Segi Gender. Jurnal Studi Keislaman dan Ilmu Pendidikan. Vol. 5 No. 2.

Lestari, E. \& Yudhanegara M. R. 2017. Penelitian Pendidikan Matematika. Bandung: PT. Refika Aditama.

M.Sudirman. S. Fatimah. \& A. Jupri. 2017. Improving Problem Solving Skill and Self Regulated Learning of Senior High School Students through Scientific Approach using Quantum Learning strategy. International Journal of Science and Applied Science.(Online). Vol. 2, No. 1 (2017).

Mulyana. A. 2015. Meningkatkan Kemampuan Penalaran Matematik Dan Kemandirian Belajar Siswa Smp Melalui Pembelajaran Berbasis Masalah. Jurnal Ilmiah STKIP Siliwangi Bandung. VOLUME 9, NOMOR 1 ISSN 1978-5089.

Nakin, J.B.N. 2003. Creativity and Divergent Thinking in Geometry Education. Dissertation of University of South Africa, (Online).

Napitupulu, E. E. 2008. Mengembangkan Kemampuan Menalar dan Memecahkan Masalah melalui Pembelajaran Berbasis Masalah (PBM). Jurnal pendidikan Matematika PARADIKMA. (Online), Vol. 1 Nomor 1, hlm. 24-33.

Napitupulu, E. Suryadi, D. \& Kusumah,Y.S. 2016. Cultivating Ultivating Upper Secondary Students' Mathematical Reasoning-Ability And Attitude Towards Mathematics Through Problem-Based Learning. Journal on Mathematics Education. (Online), Volume 7, No. 2, July 2016, pp. 117-128.

National Council of Teacher of Mathematics. 2000. Principles and Standards for School Mathematics. Reston. VA: NCTM.

Nufus, H. \& Muhamma, I. 2018. Penerapan Creative Problem Solving Berbantuan Software Autograph Untuk Meningkatkan Kemampuan Koneksi Matematika Siswa. Jurnal Pendidikan Matematika. Volume 6 No.3.

Paryatun. S, Usodo. B, \& Retno. D.S.S. 2016. Eksperimentasi Pembelajaran Matematika Dengan Model Problem Based Learning $(\mathrm{Pbl})$ Dan Learning Cycle 5e Dengan Pendekatan Saintifik Pada Materi Dimensi Tiga Ditinjau Dari Kemandirian Belajar Siswa Kelas X SMA Negeri DiKabupaten Sukoharjo Tahun Pelajaran 2014/2015. Jurnal Elektronik Pembelajaran Matematika.ISSN: 23391685 Vol.4, No.3, hal 341-351.

Permendikbud. 2006. Nomor 22 Tahun 2006 Tentang Standar Isi Pendidikan. Jakarta: Menteri Pendidikan dan Kebudayaan Republik Indonesia. 2013. Nomor 23 Tahun 2016 Tentang Standar Penilaian Pendidikan. Jakarta: Menteri Pendidikan dan Kebudayaan Republik Indonesia. 
2013. Nomor 65 Tahun 2013

Tentang Standar Proses Pendidikan Dasar dan Menengah. Jakarta: Menteri Pendidikan dan Kebudayaan Republik Indonesia.

Permana, D. \& Dian, N. W. 2014. Pengembangan Perangkat Pembelajaran Matematika Dengan Pendekatan Scientific Berorientasi Teknologi Informasi Dan Komunikasi Untuk Meningkatkan Kemampuan Pemecahan Masalah Dan Penalaran Siswa. Jakarta: Universitas Pendidikan Ganesha.

Pintrich, P.R. \& Elisabeth, D.G.V. 1990. Motivational and Self-Regulated Learning Components of Classroom Academic Performance. Journal of Educational Psychology, Vol. 82, No. 1, 33-40.

Rahmawati, A. 2014. Meningkatkan Kemampuan Pemahaman Matematika Siswa SMP Melalui Metode Penemuan Terbimbing. Prosiding Seminar Nasional Pendidikan Matematika Program Pascasarjana STKIP Siliwangi Bandung Vol 1, ISSN 23550473.

Ramdhani, M.R. Usodo, B. \& Subanti, S. 2017. Discovery Learning with Scientific Approach on Geometry. International Conference on Mathematics and Science Education (ICMScE). doi :10.1088/17426596/895/1/012033.

Rizki, R.L, Mulyono, Minarni, A. 2018. An Effort to Improve Mathematical Problem Solving Ability of Middle Secondary School Students through AutographAssisted Mathematics Realistic Education Approach. American Journal of Educational Research. Vol. 6, No. 10, 1338-1343.

Rohani, A. R. T. Suraya, A, Md, Y. Fauzi, A M A. \& Abu, K. B. 2009. Integration of Autograph Technology for Learning Algebra. European Journal of Social Sciences.(Online). Volume 9, Number 1 (2009) diakses 21 Februari 2018.

Suci F. E, Karomah, N. D, \& Cahyono .E. 2017 .Kemampuan Pemecahan Masalah Ditinjau dari Self-Efficacy Siswa dalam Implementasi Model Pembelajaran Arias Berpendekatan Saintifik. Unnes Journal of Mathematics Education Research.

Sugiyono. 2014. Metode Penelitian Pendidikan (Pendekatan Kuantatif, Kualitatif, dan R\& $D)$. Bandung: IKAPI.
Susantini, E. Kurniasari, I. Fauziah, A.N.M. Prastowo, T. Kholiq, A. \&Rosdiana, L. 2018. Engaging pre-service teachers to teach science contextually with scientific approach instructional video. The Consortium of Asia-Pacific Education Universities (CAPEU) IOP Publishing IOP Conf.

Syahputra, E. \& Surya, E. 2017. The Development of Learning Model Based on Problem Solving to Construct HighOrder Thinking Skill on the Learning Mathematics of 11th Grade in SMA/MA. Journal of Education and Practice. (Onine). Vol.8, No.6, 2017, diakses 11 Oktober 2017.

Szetela, W. \& Nicol, W. 1982. Evaluating Problem Solving in Mathematics. New York: Cambridge University Press.

Undang-Undang. Nomor 20. 2003 tentang Sistem Pendidikan Nasional.

Uno, B. H. 2011. Teori Motivasi dan pengukurannya: Analisis di Bidang Pendidikan. Jakarta: Bumi Aksara.

Winne, P.H,\& Perry, N.E. 2000. Meansuring Self Regulated Learning. In Hand Book of Self-Regulated Learning. Academic Press.

Yustitia, V. 2015. Peningkatan Kemampuan Pemecahan Masalah Melalui Pengembangan Lembar Kegiatan Siswa (Lks) Dengan Pendekatan Saintifik. Wahana.Volume 64, No 1.

Zimmerman, B.J. 2008. Investigating SelfRegulation and Motivation: Historical Background, Methodological Developments, and Future Prospects. American Educational Research Journal Math 2008. DOI: (Online),( Vol.45, No.1).

Zumbrunn, S. Taslock, J. \& Roberts, E.D. 2011. Encouraging Self-Regulated Learning in the Classroom: A Review of the Literature. Virginia Commonwealth University: Metropolitan Educational Research Consortium (MERC). 